\title{
Article
}

\section{High Concentration of Heavy Metal and Metalloid Levels in Edible Campomanesia adamantium Pulp from Anthropic Areas}

\author{
David Johane Machate 1, ${ }^{*}$, Elaine S. Pádua Melo ${ }^{2}$, Daniela G. Arakaki ${ }^{2}$, Rita de Cássia Avellaneda Guimarães ${ }^{3}$, \\ Priscila Aiko Hiane ${ }^{3}$, Danielle Bogo ${ }^{3}$, Arnildo Pott ${ }^{4}$, and Valter Aragão de Nascimento ${ }^{2, *}$
}

1 Graduate Program in Sciences of Materials, Federal University of Mato Grosso do Sul, Campo Grande 79079-900;

2 Group of Spectroscopy and Bioinformatics Applied Biodiversity and Health (GEBABS), Graduate Program in Science of Materials, Federal University of Mato Grosso do Sul, Mato Grosso do Sul 79070-900, Brazil; elainespmelo@hotmail,com (E.M.); daniarakaki@gmail.com (D.G.A.)

3 Graduate Program in Health and Development in the Central-West Region of Brazil, Federal University of Mato Grosso do Sul, Campo Grande 79079-900, Brazil; rita.guimaraes@ufms.br (R.C.A.G); priscila.hiane@ufms.br (P.A.H.);daniellebogo@hotmail.com (D.B.)

4 Graduate Program in Biotechnology and Biodiversity in the Central-West Region of Brazil, Federal University of Mato Grosso do Sul, Campo Grande 79079-900, Brazil; Arnildo Pott (A.P.)

* Correspondence: machatedavidjohanemachate@yahoo.com.br (D.J.M.); aragao60@hotmail.com (V.A.N.). Tel.: +55-67-33457413.

\begin{abstract}
This study aimed to quantify the extent of heavy metal, non-metal and metalloid level of Campomanesia adamantium pulp obtained from area crossed by road of the high large vehicle traffic and intensive agriculture modern farm, and for monitoring the health risks associated with pulp human consumption. For this purpose, three spots located between this area, ripe fruits were collected in roadside, bush and margin-farm. Pulp samples were digested by microwave-assisted equipment, and mineral elements were quantified by ICP OES. The mineral elements average demonstrated no statistical difference observed between this pulp $(p>0.05)$. The heavy metals and metalloid concentrations that exceeded $\mathrm{FAO} / \mathrm{WHO}$ standards are ordered $\mathrm{Pb}>\mathrm{As}>\mathrm{Mo}>\mathrm{Co}>\mathrm{Ni}>$ $\mathrm{Mn}>\mathrm{Cr}$. Therefore, among these metalloid and heavy metals, $\mathrm{As}, \mathrm{Pb}$ and $\mathrm{Cr}$ were found higher in farm-margin $>$ roadside $>$ bush $\left(1.5 \times 10^{-3}, 1.1 \times 10^{-3}\right.$ and $\left.6.2 \times 10^{-4}\right)$ respectively. Therefore, As is the most important metalloid with higher levels in farm-margin, roadside and bush $\left(1.5 \times 10^{-3}, 1.1 \times 10^{-3}\right.$ and $6.2 \times 10^{-4}>10^{-6}-10^{-4}$ and $3.33,2.30$ and $1.34>1$ ) respectively, to total cancer risk and hazard quotient, if $100 \mathrm{~g}$ daily of pulp are consumed.
\end{abstract}

Keywords: Cerrado; Myrtaceae; edible fruit; farm-margin; roadside; macro- and microelements; health risk.

\section{Introduction}

Native fruits contribute to food security. Heavy metal contamination of edible plants has been regarded as an environmental and public health hazard. Due to the severe anthropogenic activities, as high large-vehicle traffic and intensive modern agriculture, the environment becomes prone to high toxicity and bioaccumulation of heavy metal in plants used for food or medicines [1-3]. Among several species of plants, Campomanesia adamantium (Cambess.) O. Berg (Myrtaceae), popularly known as "Guavira or Guabiroba", stands out for its wide occurrence in the Cerrado and other biomes, as Atlantic Forest and Pampa in Brazil with intensive and intense anthropogenic activities [4]. Also, roots, leaves and fruits of this species are popularly used as antirheumatic, antidiarrheal, hypocholesterolemic, anti-inflammation, urethritis, cystitis and others [5-7]. Moreover, several studies reported the potential activities of $C$. adamantium fruits as antibacterial and antifungal [8,9], anti-hyperalgesic, antidepressive [10,11], antiproliferative against cancer cells [12,13], hepatoprotective [14], an inhibitor of leukocyte mobility, neurogenic pain and oedema [6]. The genus Campomanesia includes 37 species, and 26 are endemic in Brazil 
[4]. The C. adamantium fruits, characterized by a citrus aroma and sweet flavor, are consumed fresh or used to produce homemade liqueurs, juices, ice creams, jellies, backer products, and others [15]. Additionally, they are natural sources of a considerable amount of ascorbic acid, fibers, vegetable oil, polyphenols, and monoterpene substances $[6,13,16]$.

To date, there are only studies that have quantified minerals in the peel, pulp and seed of $C$. adamantium collected near urban areas $[17,18]$. However, no studies have been carried out on assessing chemical elements in fruits collected close to roads with high vehicle traffic in agricultural regions. Fertilizers, pesticides, and vehicle fumes contain heavy metals and metalloids, such as potassium (K), arsenic (As), iron (Fe), lead (Pb), chromium $(\mathrm{Cr})$, manganese (Mn), molybdenum (Mo), Nickel (Ni), and other elements, which in high amount contaminate the environment, edible plants and consequently humans $[1,3,19,20]$.

In view, this study aimed to quantify $\mathrm{Fe}, \mathrm{Ni}, \mathrm{Co}, \mathrm{Cr}, \mathrm{As}, \mathrm{Pb}, \mathrm{Mo}, \mathrm{Mn}, \mathrm{P}, \mathrm{K}, \mathrm{Zn}$, Se in the $C$. adamantium fruit pulp collected in three spots from the roadside $(500 \mathrm{~m})$ to bush $(1000 \mathrm{~m})$ and farm-margin $(3000 \mathrm{~m})$.

\section{Materials and Methods}

\subsection{Fruit collection and sample preparation}

We collected ripe fruits in three different spots from the roadside $(500 \mathrm{~m})$ to the bush (1000 m) and farm-margin (3000 m) in Campo Grande, Mato Grosso do Sul state, Brazil, 2046'34.208”S, 5410'28.567"W (Fig. 1), in November 2019. Manually, the pulp was separated from the peel and seed, immediately dried in an air circulation oven at $40{ }^{\circ} \mathrm{C}$ for 48 hours. The dried pulp was milled using mortar and pestle and sieved to obtain the refined powder, placed into amber and hermetic glass bottle and frozen at $-20{ }^{\circ} \mathrm{C}$ for further analyses.

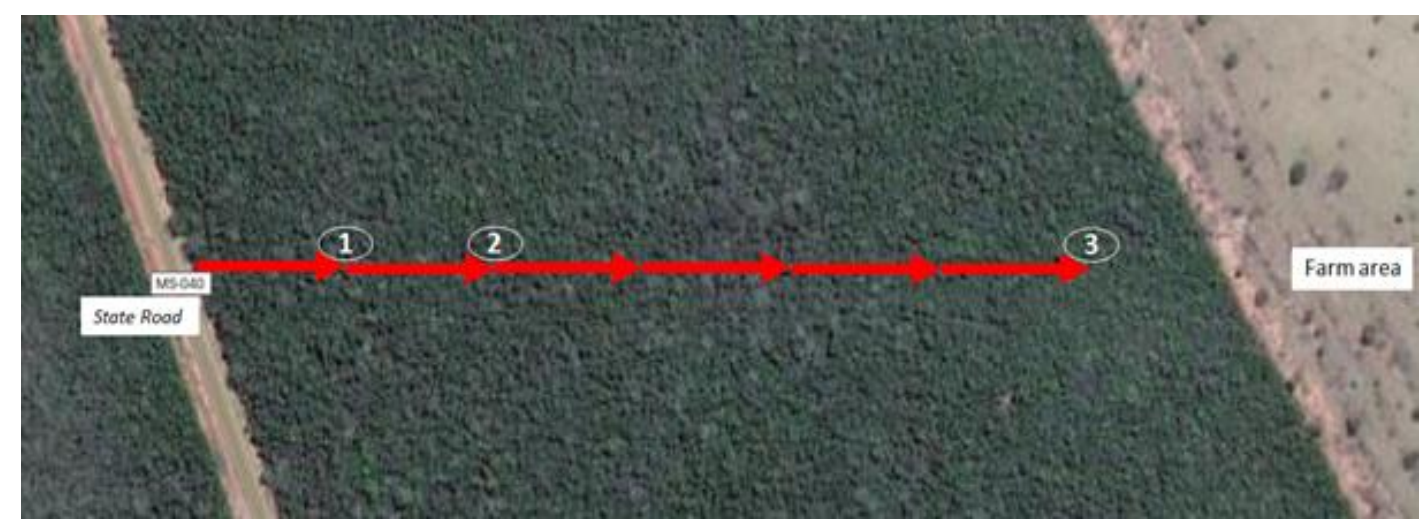

Figure 1. Collection spots of Campomanesia adamantium fruits located between the state road MS-040 with high large-vehicle traffic and intensive modern agriculture in Campo Grande - Mato Grosso do Sul State, Brazil. 1. Roadside $=500 \mathrm{~m} ; 2$. Bush = $1000 \mathrm{~m}$; and 3. Farm-margin $=3000 \mathrm{~m}$.

\subsection{Microwave assisted digestion procedure}

The pulp samples were weighed according to Lima et al. [18], and prepared as described: $0.5 \mathrm{~g}$ sample plus $5 \mathrm{~mL} \mathrm{HNO}_{3}\left(65 \%\right.$ Merck, Darmstadt, Germany) and $3 \mathrm{~mL} \mathrm{H}_{2} \mathrm{O}_{2}$ (35\% Merck, Darmstadt, Germany) were individually placed into PTFE bottles of the DAP 60 type (Berghof). The mixture was allowed to remain in the open air for 10 min predigestion and then digested using a microwave digestion system (Speedwave four ${ }^{\circledR}$, Berghof, Germany). After digestion, samples were diluted to $100 \mathrm{~mL}$ with ultrapure water (conductivity $18.2 \mathrm{M} \Omega \mathrm{cm}$ produced by Millipore, Water Purification System Milli-Q Bi- 
ocel, Germany). We conducted the sample digestion steps according to the schedule shown in Table 1. All the digestion analysis was performed in triplicate.

Table 1. Microwave digestion parameters.

\begin{tabular}{cccccc}
\hline & \multicolumn{5}{c}{ Steps } \\
\cline { 2 - 6 } & $\mathbf{1}$ & $\mathbf{2}$ & $\mathbf{3}$ & $\mathbf{4}$ & $\mathbf{5}$ \\
Power $(\mathrm{W})$ & 1305 & 1305 & 0 & 0 & 0 \\
Temperature $\left({ }^{\circ} \mathrm{C}\right)$ & 170 & 200 & 50 & 50 & 50 \\
Ramp time $(\mathrm{min})$ & 1 & 1 & 1 & 1 & 1 \\
Hold time (min) & 10 & 15 & 10 & 10 & 1 \\
Pressure (Bar) & 35 & 35 & 0 & 0 & 0 \\
\hline
\end{tabular}

\subsection{ICP OES elemental analysis}

After the microwave system's digestion procedure, we transferred the samples from the vessels to $50 \mathrm{~mL}$ Falcon vessels and then filled them to $30 \mathrm{~mL}$ with ultrapure water. Using inductively coupled plasma optical emission spectroscopy (ICP OES, Thermo Fischer Scientific, Bremen, Germany, iCAP 6300 Duo) technique, we determined the sample chemical elements. The selected emission lines (wavelength in $\mathrm{nm}$ ) for determining elements in pulp and operating conditions of ICP OES are summarized in Table 2 .

Table 2. Instrumental analytical conditions for ICP OES of element analyses.

\begin{tabular}{cc}
\hline Parameters & Setting \\
\hline RF power $(\mathrm{W})$ & 1250 \\
Sample flow rate $\left(\mathrm{L} \mathrm{mn}^{-1}\right)$ & 0.45 \\
Plasma gas flow rate $\left(\mathrm{L} \mathrm{mn}^{-1}\right)$ & 12 \\
Integration time (s) & 5 \\
Stabilization time (s) & 20 \\
Pressure of nebulization (p si) & 20 \\
Plasm view & Axial \\
Gas view & Air \\
& Fe (259.940), Ni(231.604), Co (228.616), Cr \\
Analytical wavelength (nm) & (267.716), As (193.759), Pb (214.441), Mo (202.030), \\
& $\mathrm{Mn}(257.610), \mathrm{P}(177.595), \mathrm{K}(766.490)$, \\
\hline
\end{tabular}

\subsection{Calibration curves}

For the ICP OES method, we obtained multiple-element stock solutions containing $1000 \mathrm{mg} / \mathrm{L}$ of the $\mathrm{Al}, \mathrm{As}, \mathrm{Ca}, \mathrm{Cd}, \mathrm{Co}, \mathrm{Cr}, \mathrm{Cu}, \mathrm{Fe}, \mathrm{Mg}, \mathrm{Mn}, \mathrm{Mo}, \mathrm{Na}, \mathrm{Ni}, \mathrm{P}, \mathrm{S}, \mathrm{V}$, Se, and Zn from SpecSol (SpecSol, Quimlab, Brazil), and analytical calibration standards prepared. For each element detected, a limit of detection (LOD) was $0.0002-0.003$ (mg/L), limit of quantification (LOQ) $0.006-0.01(\mathrm{mg} / \mathrm{L})$ and correlation coefficient $\left(\mathrm{R}^{2}\right)$ 0.9995-0.9998 were determined. A blank and seven calibration curves were generated using the 
following concentrations: $0.01,0.02,0.05,0.2,1.0,2.0$ and $5.0 \mathrm{mg} / \mathrm{L}$ of the element standard. All experiments were carried out in triplicates.

An addition/recovery test for the elements under study was performed in a pulp sample by spiking of $0.5 \mathrm{mg} / \mathrm{L}$ of each analyte. The method had a recovery interval of $80-110 \%$ for the spike $0.5 \mathrm{mg} / \mathrm{L}$.

\subsection{Human health risk assessment}

We compared our results with recommended intake standards of RDA/AI, UL, $\mathrm{FAO} / \mathrm{WHO}$, US. EPA and hazard quotient. The human risk for non-carcinogenic was calculated following the equation adopted by Liang et al. [20]. Cancer risk is a probability of an individual developing any cancer over a lifetime, during the daily doses exposure to 70 years; chronic daily intake dose (CDI) of carcinogenic elements $(\mathrm{mg} / \mathrm{kg} /$ day); and slope factor (SF) is the carcinogenicity (mg/kg/day). The $\mathrm{SF}$ of $\mathrm{As}, \mathrm{Cr}$ and $\mathrm{Pb}$ are $1.5,0.5$ and $0.0085 \mathrm{mg} / \mathrm{kg} /$ day, respectively, following equation 1 :

Cancer Risk $=\mathrm{CDI} \times \mathrm{SF}$

The cancer risk is a sum of individual variety carcinogenic elements risk in different exposure pathways, which is the total cancer risk (R). In agreement with US EPA [22], the value of acceptable or tolerable cancer risk ranges from $10^{-6}$ to $10^{-4}$, while $>10^{-4}$ is considered unacceptable.

The human health risk of heavy metal intake was evaluated based on the chronic daily intake dose (CDI, $\mathrm{mg} / \mathrm{kg} /$ day) for a chemical contaminant in the pulp over the exposure period and the pulp intake quantity. We calculated CDI using the following equation 2:

$\mathrm{CDI}_{\text {pulp }}=\frac{\mathrm{C}_{\text {pulp }} \times \mathrm{IR}_{\text {pulp }} \times \mathrm{EF} \times \mathrm{ED}}{\mathrm{BW} \times \mathrm{AT}}$

Where, $\mathrm{CDI}_{\text {pulp }}$ - chronic daily pulp intake dose; $\mathrm{C}_{\text {pulp }}$ - concentration of mineral content in the pulp; $\mathrm{IR}_{\text {pulp }}$ - ingestion rate (mg/day); EF - exposure frequency (day/year); ED - exposure duration (life expectancy); BW - body weight; and AT - average time (ED $\times 365$ days). The adult's body weight, approximately $70 \mathrm{~kg}$, and the average daily pulp consumption is $100000 \mathrm{mg} /$ day. The risk to human health by intake of heavy metal contaminated pulp was measured using a hazard quotient (HQ), which is a ratio of CDI and chronic oral reference dose (RfD), determined by the following equation 3 :

$$
\mathrm{HQ}=\frac{\mathrm{CDI}}{\mathrm{RfD}}
$$

The RfD values for the risk calculation were established by the Joint Food and Agriculture Organization/World Health Organization Expert Committee on Food Additives [23] and the United States Environmental Protection Agency [24]. The RfD values for the elements were established: $\mathrm{K}=$ not available, $\mathrm{Pb}=0.004 \mathrm{mg} / \mathrm{kg}$ bw/day, $\mathrm{P}=$ not available, As $=0.0003 \mathrm{mg} / \mathrm{kg} \mathrm{bw} /$ day, Se = not available, $\mathrm{Fe}=0.7 \mathrm{mg} / \mathrm{kg} \mathrm{bw} /$ day, $\mathrm{Mo}=$ not available, $\mathrm{Cu}=$ not available, $\mathrm{Mn}=0.14 \mathrm{mg} / \mathrm{kg}$ bw $/$ day $, \mathrm{Mo}=0.005 \mathrm{mg} / \mathrm{kg} \mathrm{bw} / \mathrm{day}, \mathrm{Zn}=0.3 \mathrm{mg} / \mathrm{kg}$ bw $/$ day, $\mathrm{Co}=0.03 \mathrm{mg} / \mathrm{kg}$ bw/day, $\mathrm{Ni}=0.02 \mathrm{mg} / \mathrm{kg}$ bw/day, $\mathrm{Mn}=$ not available, and $\mathrm{Cr}=$ 
$0.003 \mathrm{mg} / \mathrm{kg}$ bw/day [24]. Equation (3), toxic risk is considered to occur if $\mathrm{HQ}>1$, whereas $\mathrm{HQ}<1$ represents negligible hazard (adverse non-carcinogenic effects).

\subsection{Statistical analysis}

We analysed data by one-way ANOVA using the GraphPad Prism software version 8.0 for Mac (GraphPad Software, San Diego, CA, USA). The significance of the differences between means for individual element level was considered at $p<0.05$.

\section{Results and Discussion}

In this section, the article is composed of two subsections: 3.1 present data on the concentration of the minerals obtained in pulp collected in roadside, bush and farm-margin, and the comparison of these concentrations with other published studies. In subsection 3.2, data of the type of chemical elements quantified for each site was used to calculate EDI and HQ values.

\subsection{The mineral concentration in pulp collected in three different sites}

Twelve mineral elements were found in C. adamantium pulp collected in three different sites from the road: roadside $(500 \mathrm{~m})$, bush $(1000 \mathrm{~m})$ and farm-margin $(3000 \mathrm{~m})$ (Table 3). 
Table 3. Campomanesia adamantium pulp collected in three different sites from the road: roadside (500 $\mathrm{m})$, bush (1000 $\mathrm{m})$ and farm-margin ( $3000 \mathrm{~m})$ quantified by ICP OES (mg/100 g $\pm \mathrm{SD}$ ) compared with nutritional recommendations for adult, pregnancy and children by RDA/AI, UL and FAO/WHO.

\begin{tabular}{|c|c|c|c|c|c|c|c|c|c|c|c|}
\hline \multirow[b]{2}{*}{ Elements } & \multirow{2}{*}{$\begin{array}{l}\text { Roadside } \\
\text { (mg/100 g) }\end{array}$} & \multirow{2}{*}{$\begin{array}{c}\text { Bush } \\
\text { (mg/100 g) }\end{array}$} & \multirow{2}{*}{$\begin{array}{l}\text { Farm-margin } \\
(\mathrm{mg} / \mathbf{1 0 0} \mathrm{g})\end{array}$} & \multirow{2}{*}{$\begin{array}{c}\text { Male } \\
31-50 \text { y } \\
\text { RDA/AI* } \\
\text { (mg/day) }\end{array}$} & \multirow{2}{*}{$\begin{array}{c}\text { Female } \\
31-50 \text { y } \\
\text { RDA/AI* } \\
\text { (mg/day) }\end{array}$} & \multirow{2}{*}{$\begin{array}{c}\text { Male/ } \\
\text { female } \\
31-50 y \\
\text { UL } \\
\text { (mg/day) }\end{array}$} & \multicolumn{2}{|c|}{$\begin{array}{c}\text { Pregnancy } \\
31-50 \mathrm{y} \\
\end{array}$} & \multicolumn{2}{|c|}{$\begin{array}{c}\text { Children } \\
4-8 y\end{array}$} & \multirow{2}{*}{$\begin{array}{c}\mathrm{FAO} / \mathrm{WHO} \\
\text { (mg/day) }\end{array}$} \\
\hline & & & & & & & $\begin{array}{l}\text { RDA/AI* } \\
\text { (mg/day) }\end{array}$ & $\begin{array}{c}\text { UL } \\
\text { (mg/day) }\end{array}$ & $\begin{array}{l}\text { RDA/AI* } \\
\text { (mg/day) }\end{array}$ & $\begin{array}{c}\text { UL } \\
\text { (mg/day) }\end{array}$ & \\
\hline $\mathrm{K}$ & $33.02 \pm 0.01$ & $31.02 \pm 0.01$ & $58.01 \pm 1.34$ & 4700 & 4700 & ND & 4700 & ND & 4700 & ND & 3510 [25] \\
\hline $\mathrm{Pb}$ & $5.36 \pm 0.02$ & $7.02 \pm 0.01$ & $6.85 \pm 1.05$ & ND & ND & ND & ND & ND & ND & ND & $0.02[26]$ \\
\hline $\mathrm{P}$ & $3.24 \pm 0.02$ & $3.04 \pm 0.02$ & $5.24 \pm 0.80$ & 700 & 700 & 4000 & 700 & 3500 & 500 & 3000 & $700[25,27]$ \\
\hline As & $1.96 \pm 0.04$ & $1.14 \pm 0.03$ & $2.84 \pm 0.52$ & ND & ND & ND & ND & ND & ND & ND & $0.01[26]$ \\
\hline Se & $0.20 \pm 0.01$ & $0.22 \pm 0.02$ & $0.40 \pm 0.10$ & 55 & 55 & 400 & 400 & 60 & 30 & 150 & 0.06 [27] \\
\hline $\mathrm{Fe}$ & $0.23 \pm 0.02$ & $0.12 \pm 0.01$ & $0.40 \pm 0.10$ & 8 & 18 & 45 & 27 & 45 & 10 & 40 & 2 [28] \\
\hline Mo & $0.10 \pm 0.02$ & $0.09 \pm 0.02$ & $0.19 \pm 0.01$ & 150 & 150 & 1100 & 50 & 2000 & 22 & 600 & 0.045 [27] \\
\hline $\mathrm{Zn}$ & $0.08 \pm 0.01$ & $0.07 \pm 0.01$ & $0.13 \pm 0.02$ & 11 & 8 & 40 & 11 & 40 & 5 & 12 & 3 [27] \\
\hline Co & $0.07 \pm 0.01$ & $0.02 \pm 0.00$ & $0.08 \pm 0.02$ & $\mathrm{ND} c$ & $\mathrm{ND}_{c}$ & $\mathrm{ND} c$ & $\mathrm{ND} c$ & $\mathrm{ND} c$ & $\mathrm{ND} c$ & $\mathrm{ND}_{c}$ & 0.0014 [29] \\
\hline $\mathrm{Ni}$ & $0.06 \pm 0.01$ & $0.04 \pm 0.01$ & $0.10 \pm 0.02$ & ND & ND & 1 & ND & 1 & ND & 0.3 & 0.2 [28] \\
\hline $\mathrm{Mn}$ & $0.05 \pm 0.01$ & $0.03 \pm 0.01$ & $0.07 \pm 0.01$ & 2.30 & 1.80 & 11 & 2.60 & 11 & 1.50 & 3 & 3 [27] \\
\hline $\mathrm{Cr}$ & $0.03 \pm 0.01$ & $0.01 \pm 0.00$ & $0.05 \pm 0.01$ & $0.035^{*}$ & $0.025^{*}$ & ND & $0.030^{*}$ & ND & $0.015^{*}$ & ND & $0.002[28]$ \\
\hline
\end{tabular}


Concentration of minerals quantified in C. adamantium pulp samples are depicted in 5 decreased order in Table 3. The average concentration of minerals in pulp collected in roadside followed in decreased order $\mathrm{K}>\mathrm{Pb}>\mathrm{P}>\mathrm{As}>\mathrm{Fe}>\mathrm{Se}>\mathrm{Mo}>\mathrm{Zn}>\mathrm{Co}>\mathrm{Ni}>\mathrm{Mn}>$ Cr; bush: $\mathrm{K}>\mathrm{Pb}>\mathrm{P}>\mathrm{As}>\mathrm{Se}>\mathrm{Fe}>\mathrm{Mo}>\mathrm{Zn}>\mathrm{Ni}>\mathrm{Mn}>\mathrm{Co}>\mathrm{Cr}$, and farm-margin: $\mathrm{K}>$ $\mathrm{Pb}>\mathrm{P}>\mathrm{As}>\mathrm{Se}>\mathrm{Fe}>\mathrm{Mo}>\mathrm{Zn}>\mathrm{Co}>\mathrm{Ni}>\mathrm{Mn}>\mathrm{Cr}$. The concentration of $\mathrm{Pb}$, As and $\mathrm{Cr}$ in the present study are higher compared with the average reported for fruits and pulp by previous studies [17,18,30], which concentrations exceeded the FAO/WHO permissible limit recommended for edible berries and small fruits [25-29]. On the other hand, high concentrations of $\mathrm{Mo}, \mathrm{Co}, \mathrm{Ni}$ and $\mathrm{Mn}$ are reported in $\mathrm{C}$. adamantium fruits compared with the present study [30], which can be correlated with the occurrence of these minerals in natural environments [31,32].

In general, the average of all minerals quantified in C. adamantium pulp followed a decreasing order $\mathrm{K}>\mathrm{Pb}>\mathrm{P}>\mathrm{As}>\mathrm{Se}>\mathrm{Fe}>\mathrm{Mo}>\mathrm{Zn}>\mathrm{Co}>\mathrm{Ni}>\mathrm{Mn}>\mathrm{Cr}$. The results demonstrated no statistical difference observed between the average of minerals quantified in this pulp collected in three spots located between the road of high large-vehicle traffic and intensive farm modern agriculture $(p>0.05)$. However, a statistical difference was observed between average values of the elements found in three spots: $\mathrm{K}, \mathrm{Pb}, \mathrm{P}$, As, Se, Fe, Mo, Zn, Co, Ni, Mn and $\mathrm{Cr}(p<0.0001)$.

Thus, we observed that the concentration behavior of minerals decreased from roadside $(500 \mathrm{~m})$ to bush $(1000 \mathrm{~m})$ and increased to farm-margin $(3000 \mathrm{~m})$. However, the concentration of $\mathrm{Pb}$ and $\mathrm{Se}$ increased from roadside toward bush and toward farm-margin, as illustrated in Fig. 2.
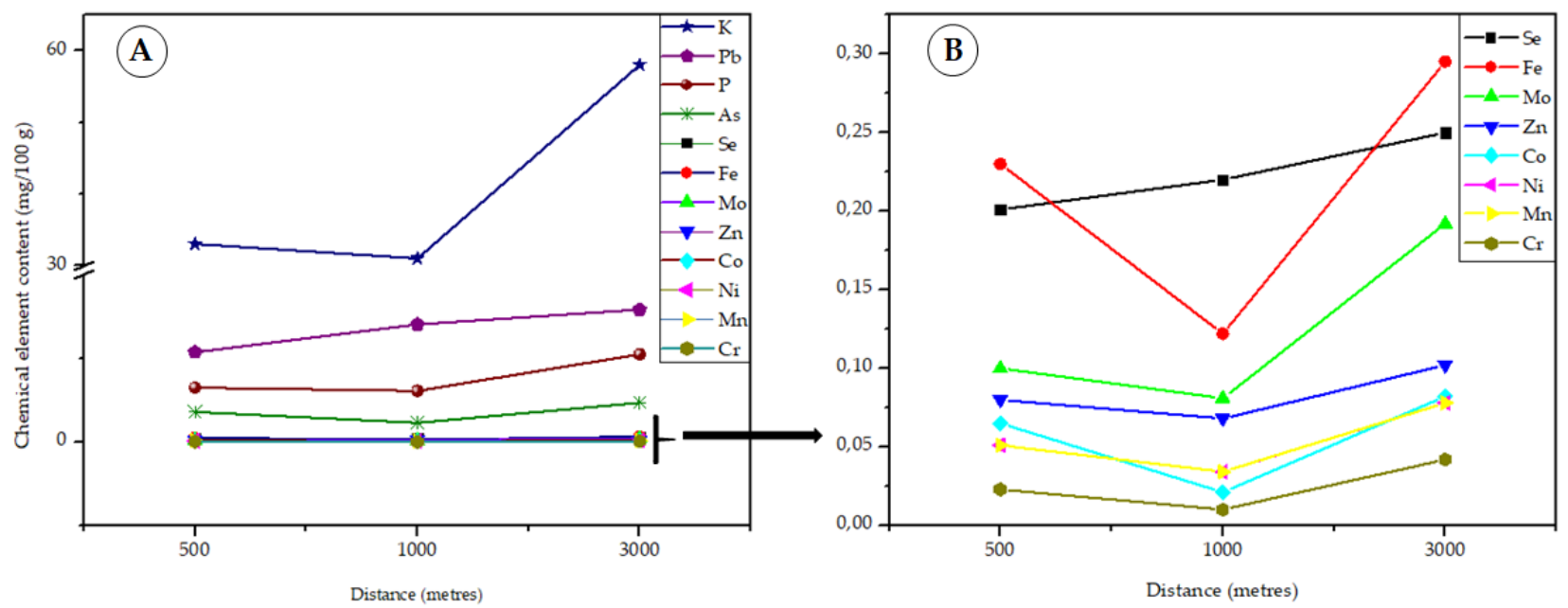

Figure 2. Behavior of mineral quantities distribution in Campomanesia adamantium pulp collected in three different sites.

A. Chemical element content $>1 \mathrm{mg} / 100 \mathrm{~g}$; B. Chemical element content $\leq 0.4 \mathrm{mg} / 100 \mathrm{~g}$.

Table 3 list the levels of minerals quantified $(\mathrm{mg} / 100 \mathrm{~g} \pm \mathrm{SD})$ in the C. adamantium pulp compared with the limit specification of RDAs/AI and UL values for males and females (31-50 y), pregnant women (31-40 y) and children (4-8 y) [33], and FAO/WHO and WHO [25-29] to permissible level for fruits and food.

We calculated the pulp mineral percentages from mean values (Table 3) based on RDA, AI, UL, and FAO/WHO and WHO limits [25-29], while based on the FDA 
parameters (10-19\% for "good source" of nutrition, and $\leq 20 \%$ for "excellent source"), the studied minerals were qualified [34].

Potassium $(\mathrm{K})$ contents in the pulp of roadside $(33.02 \pm 0.01 \mathrm{mg} / 100 \mathrm{~g})$, bush $(31.02 \pm$ $0.01 \mathrm{mg} / 100 \mathrm{~g})$ and farm-margin $(58.01 \pm 1.34 \mathrm{mg} / 100 \mathrm{~g})$ correspond to proportions $\leq 1 \%$ for males, females, pregnant women, and children to $4700 \mathrm{mg} /$ day by RDA parameters. The UL of $\mathrm{K}$ has no established values for males, females, pregnant women and children. The $\mathrm{K}$ concentration in this pulp is the lowest (3510 mg/day) FAO/WHO limit [25]. According to FDA parameters, this pulp is not a good source of $\mathrm{K}$ [34]. The $\mathrm{K}$ concentrations in this pulp are lower than $130-253 \mathrm{mg} / 100 \mathrm{~g}$ reported in previous studies for $C$. adamantium fruits and pulp $[17,18,30]$. However, $\mathrm{K}$ concentrations in this pulp are near blueberry and alfalfa (39 mg/100 g) [34]. The health benefit of $\mathrm{K}$ in the body is associated with blood pressure regulation, stroke risk reduction, preventing renal system dysfunction, decreasing urinary calcium excretion, reducing kidney stone formation and osteoporosis disease [35], regulating blood lipid concentrations [36] and maintaining bone and cardiovascular health [37,38].

Lead $(\mathrm{Pb})$ quantities in the pulp of roadside $(5.36 \pm 0.02 \mathrm{mg} / 100 \mathrm{~g})$, bush $(7.02 \pm 0.01$ $\mathrm{mg} / 100 \mathrm{~g})$ and farm-margin $(7.88 \pm 1.05 \mathrm{mg} / 100 \mathrm{~g})$ correspond to $26800 \%, 35100 \%$ and $39480 \%$ by $0.02 \mathrm{mg} /$ day FAO/WHO parameters [26]. The RDA and UL parameters for $\mathrm{Pb}$ have no established values for adults and children. Based on the FDA parameters, this pulp is an excellent source of $\mathrm{Pb}$ [34]. In this pulp, $\mathrm{Pb}$ concentrations are lower than 0.06 $\mathrm{mg} / 100 \mathrm{~g}$, reported in previous studies for fruits of C. adamantium [17]. On the other hand, $\mathrm{Pb}$ concentrations in this pulp are near other edible fruits such as apple $(2.35 \mathrm{mg} / 100 \mathrm{~g})$, mango (6.72 mg/100 g) [39] and tomato (5.41-11.73 mg/100 g) [40]. The risk of consumption of food with a high amount of $\mathrm{Pb}$ is correlated with intelligence reduction, bone joint weakness, accelerated bone maturation, increased blood pressure, spontaneous abortion, renal dysfunction, allergic diseases [41], respiratory and cardiovascular diseases [42].

Phosphorus $(\mathrm{P})$ contents in the pulp of roadside $(3.24 \pm 0.02 \mathrm{mg} / 100 \mathrm{~g})$, bush $(3.04 \pm$ $0.02 \mathrm{mg} / 100 \mathrm{~g})$ and farm-margin $(5.24 \pm 0.8 \mathrm{mg} / 100 \mathrm{~g})$ correspond to proportions $\leq 1 \%$ for males, females and pregnant women (700 mg/day) and children (500 mg/day) by RDA parameters. The $\mathrm{P}$ quantities correspond to values $\leq 0.2 \%$ for males/females (4000 $\mathrm{mg} /$ day), pregnant women (3500 mg/day) and children (3000 mg/day) by UL limits. The $\mathrm{P}$ concentrations roadside, bush and farm-margin pulp correspond to proportions $<1 \%$ to $700 \mathrm{mg} /$ day by $\mathrm{FAO} / \mathrm{WHO}$ limits [25,27]. In agreement with FDA parameters, this pulp is not a good source of $\mathrm{P}$ [27]. Indeed, $\mathrm{P}$ concentrations in this pulp are lower than 17-196 mg/100 g reported in previous studies on fruits and pulp of C. adamantium $[17,18,30]$. However, $\mathrm{P}$ concentrations in this pulp are near blackberry and watermelon (5-11 mg/100 g) [34]. The health benefit of $\mathrm{P}$ consumption is related to bone mineralization, cell energy generation, cardiovascular regulation and neuromuscular function [43], and modulation of short-chain fatty acid gut bacteria producers [44].

Arsenic (As) quantities in roadside $(1.96 \pm 0.04 \mathrm{mg} / 100 \mathrm{~g})$, bush $(1.14 \pm 0.03 \mathrm{mg} / 100 \mathrm{~g})$ and farm-margin $(2.84 \pm 0.52 \mathrm{mg} / 100 \mathrm{~g})$, correspond to $19600 \%, 11400 \%$ and $28400 \%$ by $0.01 \mathrm{mg} /$ day FAO/WHO limits [26]. The RDA and UL parameters for As have no 
established values for adults and children. By FDA parameters, this pulp is an excellent source of As [34]. The As concentrations in this pulp are higher than $0.07 \mathrm{mg} / 100 \mathrm{~g}$ reported in previous studies on C. adamantium fruits [17], and are near edible vegetables such as lettuce (2.73 mg/100g) [7], Colocasia antiquorum (0.6-12.5 mg/100 g), gourd leaf (0.8-15.8 mg/100 g) [45], fish, seafood and seafood products $(0.16-0.56 \mathrm{mg} / 100 \mathrm{~g})$ [46]. The risk of consumption of food with a high amount of As is associated with cancers (skin, lung and bladder) [45], respiratory disease, gastrointestinal disorder, liver malfunction, neuro-cardiovascular dysfunction, anaemia disorder, leucopenia and thrombocytopenia effects, diabetes [47], cytotoxicity and genotoxicity effects [48].

Selenium (Se) concentrations to the pulp of roadside $(0.20 \pm 0.01 \mathrm{mg} / 100 \mathrm{~g})$, bush $(0.22 \pm 0.02 \mathrm{mg} / 100 \mathrm{~g})$ and farm-margin $(0.40 \pm 0.1 \mathrm{mg} / 100 \mathrm{~g})$ correspond to values $<1 \%$ for males and females (55 mg/day), pregnant women (400 mg/day) and children (30 $\mathrm{mg} /$ day) by RDA parameters. The Se quantities in pulp of roadside, bush and farm-margin correspond to proportions < $1 \%$ for males and females (400 mg/day), pregnant women (60 mg/day) and children (150 mg/day) by UL limits. The Se concentrations in roadside, bush and farm-margin pulps correspond, respectively, to $333.33 \%, 366.67 \%$ and $500 \%$ by $0.06 \mathrm{mg} /$ day FAO/WHO limits [27]. According to FDA parameters, this pulp is an excellent source of Se [34]. The Se concentrations in this pulp are lower than $0.88 \mathrm{mg} / 100 \mathrm{~g}$ reported in previous studies on C. adamantium fruits [17], and higher than grapes, apricot, kiwi, litchi, macadamia and pistachio (0.0001-0.007 $\mathrm{mg} / 100 \mathrm{~g})$ and near cashew nut $(0.02 \mathrm{mg} / 100 \mathrm{~g})$ [34]. Other studies have recommended $0.018 \mathrm{mg} /$ day of Se quantity intake for children (4-6 y), $0.023 \mathrm{mg} /$ day for adolescent males 10-18 y and $0.021 \mathrm{mg} /$ day for adult females (19-65 y), 0.027 mg/ day for males and $0.0204 \mathrm{mg} /$ day [49]. The benefit of consumption of Se is correlated with preventing and decreasing diabetes mellitus, cancers [50], ameliorate men fertility [51,52], human neuropathies [53] and hepatic steatosis [54].

Iron $(\mathrm{Fe})$ concentrations to the pulp of roadside $(0.23 \pm 0.02 \mathrm{mg} / 100 \mathrm{~g})$, bush $(0.12 \pm$ $0.01 \mathrm{mg} / 100 \mathrm{~g})$ and farm-margin $(0.40 \pm 0.10 \mathrm{mg} / 100 \mathrm{~g})$ correspond to values $<4 \%$ by RDA parameters for males (8 mg/day), females (18 mg/day), pregnant women (27 $\mathrm{mg} /$ day) and children (10 mg/day). The Fe quantity in the pulp of roadside, bush and farm-margin correspond to $<1 \%$ by UL parameters for males, females and pregnant women (45 mg/day) and children (40 mg/day). In concordance with FDA parameters, this pulp is not a good source of Fe [34]. The Fe concentrations in this pulp are lower than $1-2.6 \mathrm{mg} / 100 \mathrm{~g}$ reported in previous studies on fruits and pulp of $C$. adamantium $[17,18,30]$. However, the Fe contents of this pulp are between apple, guava and pineapple $(0.12-0.29 \mathrm{mg} / 100 \mathrm{~g})$ [34]. The health benefits of food consumption with Fe are improving maximal oxygen respiration and exercise performance, hemoglobin synthesis, electron transport, anemia prevention, deoxyribonucleic acid synthesis, gut microbiota modulation, neurodevelopment, immunity, pregnancy development [55-57].

Molybdenum (Mo) concentrations to the pulp of roadside $(0.10 \pm 0.02 \mathrm{mg} / 100 \mathrm{~g})$, bush $(0.09 \pm 0.02 \mathrm{mg} / 100 \mathrm{~g})$ and margin-farm $(0.19 \pm 0.01 \mathrm{mg} / 100 \mathrm{~g})$ correspond to proportions $\leq 1 \%$ by RDA parameters for males and females (150 mg/day), pregnant women (50 mg/day) and children (22 mg/day). The Mo contents in the pulp of roadside, 
bus and farm-margin correspond to values $\leq 0.2 \%$ by UL parameters for males and females (1100 mg/day), pregnant women (2000 mg/day) and children (600 mg/day). The Mo concentrations in pulp to roadside, bush and farm-margin correspond respectively to $222.22 \%, 177.78 \%$ and $422.22 \%$ by $0.045 \mathrm{mg} /$ day $\mathrm{FAO} / \mathrm{WHO}$ parameters [27]. In agreement with FDA parameters, this pulp is an excellent source of Mo [34]. However, the Mo concentrations in this pulp are lower than $0.4-30 \mathrm{mg} / 100 \mathrm{~g}$ reported in previous studies on fruits of C. adamantium [18,30]. The Mo food consumption is recommended for infants (0.015-0.04 mg/day) and all individuals $\geq 10$ years old $(0.025-0.15 \mathrm{mg} /$ day [58]. The health benefit of Mo is correlated with toxicity prevention by several metabolites, reduction of aerosol organs irritability, night blindness, neurological damage, aches and pain [59-61]. The Mo concentrations of this pulp are between pea seeds and tomato (0.10-0.20 mg/100 g) [62].

Zinc $(\mathrm{Zn})$ concentrations to the pulp of roadside $(0.08 \pm 0.01 \mathrm{mg} / 100 \mathrm{~g})$, bush $(0.07 \pm$ $0.01 \mathrm{mg} / 100 \mathrm{~g})$ and farm-margin $(0.13 \pm 0.02 \mathrm{mg} / 100 \mathrm{~g})$ correspond to values < $2 \%$ by RDA limits for males and pregnant women $(11 \mathrm{mg} /$ day $)$, females ( $8 \mathrm{mg} /$ day $)$ and children ( $5 \mathrm{mg} /$ day). The $\mathrm{Zn}$ quantity in pulps of roadside, bush and farm-margin corresponds to $1 \%$ by UL parameters for males, females, pregnant women (40 mg/day) and children (12 $\mathrm{mg} /$ day). The $\mathrm{Zn}$ concentrations in this pulp correspond to $2.67 \%, 2.27 \%$ and $3.4 \%$ by 3 $\mathrm{mg} /$ day FAO/WHO limits [27]. Based on FDA parameters, this pulp is not a good source of $\mathrm{Zn}$ [27]. The $\mathrm{Zn}$ concentrations in this pulp are lower compared with $0.2-0.5 \mathrm{mg} / 100 \mathrm{~g}$ reported in previous studies on fruits and pulp of $C$. adamantium $[17,18,30]$. However, the $\mathrm{Zn}$ amounts are between apple, grapes and tomato $(0.04-0.17 \mathrm{mg} / 100 \mathrm{~g})$ [34]. The health benefit of consumption of $\mathrm{Zn}$ food is associated with preventing or reducing oxidative stress, infections (malaria, pneumonia and diarrhea), cell ageing, atherosclerosis, neuropsychological diseases, autoimmune and degenerative diseases, Alzheimer's disease, inflammation cytokine storms, cancers, diabetes mellitus, obesity, depression, gastrointestinal and reproductive organ dysfunction, retina disease, and improving fetal and childhood skeletal growth and development [63-65].

Cobalt (Co) concentrations to the pulp of roadside $(0.07 \pm 0.01 \mathrm{mg} / 100 \mathrm{~g})$, bush $(0.02$ $\pm 0.00 \mathrm{mg} / 100 \mathrm{~g})$ and farm-margin $(0.08 \pm 0.02 \mathrm{mg} / 100 \mathrm{~g})$ correspond to $5000 \%, 1428.57 \%$ and $5714.29 \%$ by $0.0014 \mathrm{mg} /$ day WHO limits [29]. The RDA and UL parameters for Co have no established value for adults and children. Conforming to FDA parameters, this pulp is an excellent source of Co [34]. The Co concentrations in this pulp are lower than 8 $\mathrm{mg} / 100 \mathrm{~g}$ reported in previous studies on C. adamantium pulp [30]. The Co concentrations are between strawberries, apple, grapes, mango, tomato and orange $(0.03-0.08 \mathrm{mg} / 100 \mathrm{~g})$ [39]. The risk of consumption of food with a high amount of Co is correlated with inflammation and hypersensitivity reactions [66], neurological, cardiovascular and endocrine deficiency [67].

Nickel (Ni) concentrations to the pulp of roadside $(0.06 \pm 0.01 \mathrm{mg} / 100 \mathrm{~g})$, bush $(0.04$ $\pm 0.01 \mathrm{mg} / 100 \mathrm{~g})$ and $(0.1 \pm 0.02 \mathrm{mg} / 100 \mathrm{~g})$ correspond $6 \%, 4 \%$ and $10 \%$ for male, female, pregnant women, and $20 \%, 13.33 \%$ and $33.33 \%$ for children, respectively by $1 \mathrm{mg} / \mathrm{day}, 1$ $\mathrm{mg} /$ day and $0.3 \mathrm{mg} /$ day UL limits. The Ni concentrations of the roadside, bush and farm-margin correspond $30 \%, 20 \%$ and $50 \%$ by $0.2 \mathrm{mg} /$ day FAO/WHO limits [28]. The 
RDA parameters for $\mathrm{Ni}$ has no established value for adults and children. According to FDA parameters, this pulp is an excellent source of $\mathrm{Ni}$ [34]. The Ni concentrations in this pulp are lower than $4.2 \mathrm{mg} / 100 \mathrm{~g}$ reported in previous studies on fruits of C. adamantium [17]. The Ni concentrations are between paw-paw, mango, watermelon and banana fruits (0.023-0.089 mg/100 g) [68]. Some articles reported the health benefit of $\mathrm{Ni}$ food consumption is correlated with gut microbiota balance, welfare [69]. However, other studies correlated $\mathrm{Ni}$ with hazardous conditions for human health such as cardiovascular, kidney and lung dysfunctions, oxidative stress and others [70].

Manganese $(\mathrm{Mn})$ contents to pulps of roadside $(0.05 \pm 0.01 \mathrm{mg} / 100 \mathrm{~g})$, bush $(0.03 \pm$ $0.01 \mathrm{mg} / 100 \mathrm{~g})$ and farm-margin $(0.07 \pm 0.01 \mathrm{mg} / 100 \mathrm{~g})$ correspond to values $\leq 4 \%$ for males (2.3 mg/day), females (1.8 mg/day), pregnant women (2.6 mg/day) and children $(1.5 \mathrm{mg} /$ day) by RDA parameters. The Mn quantities correspond to proportions $<2.5 \%$ for males/females and pregnant women (11 mg/day), and children (3 $\mathrm{mg} /$ day) by UL limits. The Mn concentrations in pulps of roadside, bush and farm-margin correspond to $1.33 \%, 1.00 \%$ and $2.33 \%$, respectively, by $3 \mathrm{mg} /$ day FAO/WHO limits [27]. By FDA parameters, this pulp is not a good source of Mn [34]. The Mn concentrations in this pulp are lower than $0.09-0.21 \mathrm{mg} / 100 \mathrm{~g}$ reported to previous studies on fruits and pulp of $C$. adamantium $[17,18,30]$. However, the Mn contents are near paw-paw and wheat $(0.08-1.0$ $\mathrm{mg} / 100 \mathrm{~g}$ ) [71]. The health benefit of consumption of Mn food is associated with gut microbiota balance, regulating oxygen species and anemia conditions between mother and fetus, and neurodevelopment [72-74].

Chromium $(\mathrm{Cr})$ concentration to the pulp of roadside was $0.03 \pm 0.01 \mathrm{mg} / 100 \mathrm{~g}$ corresponds to $116.67 \%, 83.33 \%, 100 \%$ and $50 \%$ for males $(0.035 \mathrm{mg} /$ day $)$, females $(0.025$ $\mathrm{mg} /$ day $)$, pregnant women $(0.03 \mathrm{mg} /$ day $)$ and children $(0.015 \mathrm{mg} /$ day $)$ by AI parameters. The bush Cr quantity of $0.01 \pm 0.00 \mathrm{mg} / 100 \mathrm{~g}$ in pulp corresponds to $350 \%, 250 \%, 300 \%$, and $150 \%$ for males, females, pregnant women and children, respectively, by AI limits. The farm-margin Cr content was $0.05 \pm 0.01 \mathrm{mg} / 100 \mathrm{~g}$ corresponds to $70 \%, 50 \%, 60 \%$, and $30 \%$ for males, females, pregnant women and children, respectively, by AI standard. The $\mathrm{Cr}$ quantities in the pulp of roadside, bush and farm-margin correspond to $6.67 \%, 20 \%$ and $4 \%$, respectively, by $0.002 \mathrm{mg} /$ day $\mathrm{FAO} / \mathrm{WHO}$ limits [28]. The RDA and UL parameters for $\mathrm{Cr}$ have no established values for adults and children. According to FDA parameters, this pulp is a good source of $\mathrm{Cr}$ [34]. However, the $\mathrm{Cr}$ concentrations in this pulp are lower than $0.1-1.14 \mathrm{mg} / 100 \mathrm{~g}$ reported by previous studies on C. adamantium pulp $[18,30]$. The $\mathrm{Cr}$ contents are near edible fruits such as strawberry and melon $(0.3$ $\mathrm{mg} / 100 \mathrm{~g})$ [75].

\subsection{Health risk assessment}

We calculated the carcinogenic risk (CR) of three chemical elements $\mathrm{Pb}, \mathrm{As}$ and $\mathrm{Cr}$ in pulp obtained from fruits collected in roadside, bush and farm-margin (Table 4). The values of $\mathrm{As}$ and $\mathrm{Cr}$ were farm-margin > roadside $>$ bush, while the $\mathrm{Pb}$ values differed (farm-margin $>$ bush $>$ roadside). The total cancer risk $(\mathrm{R})$ values for farm-margin, roadside and bush were $1.5 \times 10^{-3}, 1.1 \times 10^{-3}$ and $6.2 \times 10^{-4}$, respectively, which were higher compared with the acceptable parameters $\left(10^{-6}\right.$ to $\left.10^{-4}\right)$, showing the importance of these 
values to carcinogenic risk for the pulp consumers [22]. The total cancer risk is presented in decreased order $\mathrm{As}>\mathrm{Pb}>\mathrm{Cr}$, demonstrating that $\mathrm{As}$ is the main pollutant chemical element that can be correlated with several cancer incidences among all heavy metals found in this pulp. Furthermore, the total cancer risk incidence can be higher for the consumers intake $400 \mathrm{~g} /$ day pulp as recommended [76], from farm-margin, roadside and bush $\left(6.0 \times 10^{-3}, 4.1 \times 10^{-3}\right.$ and $2.4 \times 10^{-3}$, respectively $)$, in the region crossed by a road of high large-vehicle traffic and intensive modern agriculture. However, the total cancer risk for consumption of $10 \mathrm{~g} / \mathrm{kg} /$ day of pulp from the roadside, bush and farm-margin was estimated to $1.1 \times 10^{-4}, 6.3 \times 10^{-5}$ and $1.5 \times 10^{-4}$, respectively, which are within acceptable parameters [22].

The non-carcinogenic risks for mineral elements are summarized in Table 4 . The CDI values of the minerals in fruit pulp are presented in decreased order for three collection sites: $\mathrm{K}>\mathrm{Pb}>\mathrm{P}>\mathrm{As}>\mathrm{Fe}>\mathrm{Se}>\mathrm{Mo}>\mathrm{Zn}>\mathrm{Co}>\mathrm{Ni}>\mathrm{Mn}>\mathrm{Cr}$ for roadside, $\mathrm{K}>$ $\mathrm{Pb}>\mathrm{P}>\mathrm{As}>\mathrm{Se}>\mathrm{Fe}>\mathrm{Mo}>\mathrm{Zn}>\mathrm{Co}>\mathrm{Ni}>\mathrm{Mn}>\mathrm{Cr}$ for bush and $\mathrm{K}>\mathrm{Pb}>\mathrm{P}>\mathrm{As}>\mathrm{Se}=$ $\mathrm{Fe}>\mathrm{Mo}>\mathrm{Zn}>\mathrm{Ni}>\mathrm{Co}>\mathrm{Mn}>\mathrm{Cr}$ for farm-margin. The ordered quantities of mineral elements are different for $\mathrm{Fe}$ and Se from roadside, while Se, Fe, $\mathrm{Ni}$ and $\mathrm{Co}$ for farm-margin compared with bush areas. The major chemical elements in the pulp in decreased order are farm-margin $>$ roadside $>$ bush, which signifies that the farm and road have spread these minerals to pollute fruits. In contrast, $\mathrm{Pb}$ and Se are ordered from farm-margin > bush $>$ roadside, which explains that the highest amount of these chemical elements have spread from the farm.

The hazard quotient (HQ) values of the minerals in pulp estimated in decreased order to roadside were $\mathrm{As}>\mathrm{Pb}>\mathrm{Mo}>\mathrm{Cr}>\mathrm{Ni}>\mathrm{Co}>\mathrm{Fe}>\mathrm{Mn}>\mathrm{Zn}$; bush: $\mathrm{As}>\mathrm{Pb}>\mathrm{Mo}>$ $\mathrm{Cr}>\mathrm{Ni}>\mathrm{Co}>\mathrm{Fe}>\mathrm{Zn}>\mathrm{Mn}$; and farm-margin: $\mathrm{As}>\mathrm{Pb}>\mathrm{Mo}>\mathrm{Cr}>\mathrm{Ni}>\mathrm{Co}>\mathrm{Mn}>\mathrm{Fe}>$ $\mathrm{Zn}$. The quantities of $\mathrm{Mn}, \mathrm{Fe}$ and $\mathrm{Zn}$ are irregularly distributed in farm-margin, roadside and bush areas. The majority of chemical elements are ordered to farm-margin > roadside $>$ bush, which explains that farm and road are sources of higher amounts of these minerals. In contrast, $\mathrm{Pb}$ is ordered from farm-margin $>$ bush $>$ roadside, meaning that this mineral has spread in a higher amount from the farm. The majority of minerals presented $\mathrm{HQ}<1$, while As highest values in farm-margin, roadside and bush were 3.33, 2.30 and 1.34, respectively. Therefore, at the consumption of $100 \mathrm{~g} / \mathrm{kg} /$ day of pulp, As could be the main cause of several cancer types and other chronic diseases. 
Table 4. Carcinogenic risk (CR), chronic daily intake dose (CDI, $\mathrm{mg} / \mathrm{kg}$ bw/day) and hazard quotient (HQ) of elements through pulp collected in three different sites from the road: roadside $(500 \mathrm{~m})$, bush $(1000 \mathrm{~m})$ and farm-margin $(3000 \mathrm{~m})$.

\begin{tabular}{|c|c|c|c|c|c|c|c|c|c|c|c|c|c|}
\hline Samples & & $\mathbf{K}$ & $\mathrm{Pb}$ & $\mathbf{P}$ & As & Se & Fe & Mo & Zn & Co & $\mathrm{Ni}$ & Mn & $\mathrm{Cr}$ \\
\hline \multirow{3}{*}{ Roadside } & CR & - & 0.000016 & - & 0.001036 & - & - & - & - & - & - & - & 0.0000053 \\
\hline & CDI & 0.011631 & 0.001888 & 0.001141 & 0.000690 & 0.000070 & 0.000081 & 0.000035 & 0.000028 & 0.000025 & 0.000021 & 0.000018 & 0.000011 \\
\hline & $\mathrm{HQ}$ & - & 0.472016 & - & 2.301370 & - & 0.000116 & 0.007045 & 0.000094 & 0.000822 & 0.001057 & 0.000126 & 0.003523 \\
\hline \multirow{3}{*}{ Bush } & CR & - & 0.000021 & - & 0.000602 & - & - & - & - & - & - & - & 0.0000018 \\
\hline & CDI & 0.010927 & 0.002473 & 0.001071 & 0.000402 & 0.000077 & 0.000042 & 0.000032 & 0.000025 & 0.000007 & 0.000014 & 0.000011 & 0.000004 \\
\hline & HQ & - & 0.618200 & - & 1.338552 & - & 0.000060 & 0.006341 & 0.000082 & 0.000235 & 0.000705 & 0.000075 & 0.001174 \\
\hline \multirow{3}{*}{ Farm-margin } & $\mathrm{CR}$ & - & 0.000024 & - & 0.001501 & - & - & - & - & - & - & - & 0.0000088 \\
\hline & CDI & 0.020435 & 0.002779 & 0.001846 & 0.001000 & 0.000141 & 0.000141 & 0.000067 & 0.000046 & 0.000028 & 0.000035 & 0.000025 & 0.000018 \\
\hline & $\mathrm{HQ}$ & - & 0.694814 & - & 3.334638 & - & 0.000201 & 0.013386 & 0.000153 & 0.000939 & 0.001761 & 0.000176 & 0.005871 \\
\hline
\end{tabular}




\section{Conclusions}

According to RDA and UL limits, the pulp of C. adamantium collected in areas located between the road of high large-vehicle traffic and intensive modern agriculture farm present the lowest concentration of $\mathrm{K}, \mathrm{P}, \mathrm{Se}, \mathrm{Fe}, \mathrm{Mo}, \mathrm{Zn}, \mathrm{Ni}$, and $\mathrm{Mn}$. However, based on $\mathrm{FAO} / \mathrm{WHO}$ parameters, the highest concentrations are $\mathrm{Pb}, \mathrm{As}, \mathrm{Se}, \mathrm{Mo}$, $\mathrm{Co}$ and $\mathrm{Ni}$, and the lowest for $\mathrm{K}, \mathrm{P}, \mathrm{Fe}, \mathrm{Zn}$ and $\mathrm{Mn}$. The $\mathrm{Cr}$ concentration is higher than $\mathrm{FAO} / \mathrm{WHO}$ and AI limits. Values of $\mathrm{Pb}, \mathrm{As}, \mathrm{Co}$ and $\mathrm{Cr}$ are not established by RDA and UL standards, including $\mathrm{K}$, not established for the last parameter. This pulp is an excellent source of $\mathrm{Pb}, \mathrm{As}$, Se, $\mathrm{Mo}, \mathrm{Co}, \mathrm{Ni}$ and $\mathrm{Cr}$, while it is not a good source of $\mathrm{K}, \mathrm{P}, \mathrm{Fe}$, $\mathrm{Zn}$ and $\mathrm{Mn}$, based on FDA parameters. It is notable that plants that grow and develop between intensive anthropogenic and severe activities are contaminated by heavy metals such as $\mathrm{Pb}, \mathrm{As}, \mathrm{Mo}, \mathrm{Co}, \mathrm{Ni}, \mathrm{Mn}$ and $\mathrm{Cr}$. Additionally, the concentrations of these heavy metals increase, while K, P, Fe and $\mathrm{Zn}$ decrease, except Se. Thus, the consumption of plants collected in these environments can be a hazard to human health. Therefore, toxicological studies can be needed to guarantee the safe consumption of edible plants collected in areas under intensive severe anthropogenic activities.

Overall, the estimated carcinogenic risk and total cancer risk in this pulp are represented by $\mathrm{As}, \mathrm{Pb}$ and $\mathrm{Cr}$, which are in higher concentrations in pulp collected in farm-margin, followed by roadside and bush. Thus, the primary crucial heavy metal is As, presenting $\mathrm{HQ}>1(3.33,2.30$ and 1.34 in pulp collected in farm-margin, roadside and bush, respectively). However, quantities $\leq 10 \mathrm{~g}$ daily intake of pulp obtained in these areas can decrease the total cancer risk and are within accepted parameters and $\mathrm{HQ}<1$ for all minerals assessed in this pulp. We demonstrated that intensive agriculture modern farms and areas crossed by roads of large-vehicle traffic are sources and flow of pollutants to contaminate fruits and vegetables that grow in surrounding areas.

Author Contributions: Conceptualization, D.J.M. and V.A.N., methodology, D.J.M., V.A.N. and E.M.; formal analysis, D.J.M. and V.A.N.; investigation, D.J.M., and V.A.N; writing-original draft preparation, D.J.M.; V.A.N. writing-review and editing, D.J.M., V.A.N., R.C.A.G., P.A.H., D.B., A.P., E.M.; visualization, D.J.M. and V.A.N.; supervision, D.J.M. and V.A.N.; project administration, V.A.N. All authors have read and agreed to the published version of the manuscript.

Funding: This research was funded by Federal University of Mato Grosso do Sul-UFMS and Coordination of Superior Level Staff Improvement (CAPES).This study was financed in part by the CAPES - finance code 001.

Acknowledgments: We thank Graduate Program in Sciences of Materials, Federal University of Mato Grosso do Sul, Graduate Program in Health and Development in the Central-West Region of Brazil, Graduate Program of Biotechnology of Federal University of Mato Grosso do Sul - UFMS, Brazil for support. The authors thank the Coordination for the Improvement of Higher Education Personal (Coordenação de aperfeiçoamento de Pessoal de Nível Superior _ CAPES) and the National Council for Scientific and Technological Development (Conselho Nacional de Desenvolvimento Científico e Tecnológico - CNPq) for research grants.

Conflicts of Interest: The authors declare no conflict of interest. 
1. Srivastava, V.; Sarkar, A.; Singh, S.; Singh, P.; Araujo, A.S.F.; Singh, R.P. Agroecological responses of heavy metal pollution with special emphasis on soil health and plant performances. Front. Environ. Sci. 2017, 5, 64, doi:10.3389/fenvs.2017.00064.

2. Margenat, A.A.; Matamoros, V.; Díez, S.; Cañameras, N.; Comas, J.; Bayona, J.M. Occurrence and human health implications of chemical contaminants in vegetables grown in peri-urban agriculture. Environ. Int. 2019, 124, 49-57,https://doi.org/10.1016/j.envint.2018.12.013.

3. Rai, P.K.; Lee, S.S.; Zhang, M.; Tsang, Y.F.; Kim, K.H. Heavy metals in food crops: Health risks, fate, mechanisms, and management. Environ. Int. 2019, 125, 365-385, https://doi.org/10.1016/j.envint.2019.01.067.

4. Campomanesia in Flora do Brasil 2020 underconstruction. Jardim Botânico do Rio de Janeiro. Available online: http://floradobrasil.jbrj.gov.br/reflora/floradobrasil/FB10307(accessedon 11March 2021).

5. Lescano, C.H.; Oliveira, I.P.; Zaminelli, T.; Baldivia, D.S.; Silva, L.R.; Napolitano, M.; Silvério, C.B.M.; Lincopan, N.; Sanjinez-Argandoña, E.J. Campomanesia adamantiumpeelextract in antidiarrhealactivity: The ability of inhibition of heat-stableenterotoxinbypolyphenols. PLos One2016, 11, e0165208, doi:10.1371/journal.pone.0165208.

6. Viscardi, D.Z.; Arrigo, J.S.; Correia, C.A.C.; Kassuya, C.A.L.; Cardoso, C.A.L.; Maldonade, I.R.; Argandoña, E.J.S. Seed and peel essential oils obtained from Campomanesia adamantium fruit inhibit inflammatory and pain parameters in rodents. Plos One 2017, 12, e0157107, https://doi.org/10.1371/journal.pone.0157107.

7. Oliveira, L.M.; Suchismita, D.; Gress, J.; Rathinasabapathi, B.; Chen, Y.; Ma, L.Q. Arsenic uptake by lettuce from As - contaminated soil remediated with Pterisvittata and organic amendment. Chemosphere2017, 176, 249-254, doi:10.1016/j.chemosphere.2017.02.124.

8. Pavan, F.R.; Leite, C.Q.F.; Coelho, R.G.; Coutinho, I.D.; Honda, N.K.; Cardoso, C.A.L.; Vilegas, W.; Leite, S.R.A.; Sato, D.N. Evaluation of anti-Mycobacterium tuberculosis activity of Campomanesia adamantium (Myrtaceae).Quim. Nova2009, 32, 1222-1226, doi:10.1590/S0100-40422009000500026.

9. Cardoso, C.A.L.; Salmazzo, G.R.; Honda, N.K.; Prates, C.B.; Vieira, M.C.; Coelho, R.G. Antimicrobial activity of the extracts and fractions of hexanic fruits of Campomanesia species (Myrtaceae). J. Med. Food. 2010, 13, 1273-1276, doi:10.1089/jmf.2009.0047.

10. Souza, J.C.S.; Piccinelli, A.C.; Aquino, D.F.S.; Souza, V.V.; Schmitz, W.O.; Traesel, G.K.; Cardoso, C.A.L.; Kassuya, C.A.L.; Arena, A.C. Toxicological analysis and antihyperalgesic, antidepressant, and anti-inflammatory effects of Campomanesia adamantium fruit bark. Nutr. Neurosci.2017, 20, 23-31, https://doi.org/10.1179/1476830514Y.0000000145.

11. Cardoso, C.A.L.; Kassuya, C.A.L.; Arena, A.C. Toxicological analysis and antihypealgesic, antidepressant, and anti-intiflammatory effects of Campomanesia adamantium fruit barks. Nutr. Neurosci. 2017, 20, 23-31, doi:10.1179/1476830514Y.0000000145.

12. Pascoal, A.C.R.; Ehrenfried, C.A.; Lopez, B.G.C.; Araujo, T.M.; Pascoal, V.A.B.; Gioli, R.; Anê, G.F.; Ruiz, A.L.T.G.; Carvalho, J.E.; et al. Antiproliferative activity and induction of apoptosis in PC-3 cells by the chalcona cardamonina from Campomanesia adamantium (Myrtacea) in a bioactivity - guided study. Molecules 2014, 19, 1843-1855, doi:10.3390/molecules19021843.

13. Lima e Silva, M.C.B.; Bogo, D.; Alexandrino, C.A.F., Perdomo, R.T., Figueiredo, P.O., Prado, P.R., Gaecez, F.R., Kadri, M.C.T., Ximenes, T.V.N., Guimarães, R.C.A., et al. Antiproliferative activity of extracts of Campomanesia adamantium (Cambess.) O. Berg and isolated compound dimethylchalcone against B16-F10 murine melanoma. J. Med. Food 2018, 21, 10, 1024-1034, doi:10.1089/jmf.2018.0001.

14. Fernandes, T.O.; Ávila, R.I.; Moura, S.S.; Ribeiro, G.A.; Naves, M.M.V.; Valadares, M.C. Campomanesia adamantium (Myrtaceae) fruits protect HEPG2 cells against carbon tetrachloride-induced toxicity. Toxic. Rep. 2015, 2, 184-193, https://doi.org/10.1016/j.toxrep.2014.11.018.

15. Bortolotto, I.M.; Hiane, P.A.; Ishii, I.H.; Souza, P.R.; Campos, R.P.; Gomes, R.J.B.; Farias, C.S.; et al.; A knowledge network to promote the use and valorization of wild food plants in the Pantanal and Cerrado, Brazil. Reg. Environ. Change2017, 17, 1329-1341,doi:10.1007/s10113-016-1088-y. 
16. Machate, D.J.; Candido, C.J.; Inada, A.C.; Franco, B.C.; Carvalho, I.R.A.; Oliveira, L.C.S.; Cortes, M.R.; Caires, A.R.L.; Silva, R.H.; Hiane, P.A.; Bogo, D.; Lima, N.V.; Nascimento, V.A.; Guimarães, R.C.A.; Pott, A. Fattyacid profile and physicochemical, optical and termal characteristics of Campomanesia adamantium (Cambess.) O. Berg seed oil. Food Sci. Technol. 2020, 40, 538-544, https://doi.org/10.1590/fst.32719.

17. Vallilo, M.I.; Lamardo, L.C.A.; Gaberlotti, M.L.; Oliveira, E. Moreno, P.R.H. Composição química dos frutos de Campomanesia adamantium (Cambesséde) O. Berg. Ciên. Tecnol. Aliment.2006, 26, 805-810, http://dx.doi.org/10.1590/S0101-20612006000400015.

18. Lima, N.V.; Arakaki, D.G.; Tscinkel, P.F.S.; Silva, A.F.; Guimarães, R.C.A.; Hiane, P.A.; Ferreira-Júnior, M.A.; Nascimento, V. A. Firstcomprehensivestudyon total determination of nutritionalelements in thefruit of theCampomanesia adamantium (Cambess.): Brazilian Cerrado Plant. Int. Arch. Med. 2016, 9, 350, 1-11, doi:10.3823/2221.

19. Tóth, G.; Hermann, T.; Da Silva, M.R.; Montanarella, L. Heavy metals in agricultural soils of the European Union with implications for food safety. Environ. Int. 2016, 88, 299-309, http://dx.doi.org/10.1016/j.envint.2015.12.017.

20. Antoniadis, V.; Golia, E.E.; Liu, Y.T.;Wang, S.L.; Shaheen, S.M.; Rinklebe, J. Soil and maize contamination by trace elements and associated health risk assessment in the industrial area of Volos, Greece. Environ. Int. 2019, 124, 79-88, https://doi.org/10.1016/j.envint.2018.12.053.

21. Liang, Y.; Yi, X.; Dang, Z.; Wang, Q.; Luo, H.; Tang, J. Heavy metal contamination and health risk assessment in the vicinity of a tailing pond in Guangdong, China. Int. J. Environ. Res. Public Health2017, 14, 1557, doi:10.3390/ijerph14121557.

22. United States Environmental Protection Agency (U.S. EPA). Risk Assessment Guidance for Superfund, Volume I: Human Health Evaluation Manual; Office of Emergency and Remedial Response: Washington, DC, USA, 1989; pp. 1-288.

23. JECFA WHO. Summary and Conclusions of the 61st Meeting of the Joint FAO/WHO Expert Committee on Food Additives; JECFA WHO: Rome, Italy, 2003; pp. 1-188.

24. USEPA IRIS Program Information about the Integrated Risk Information System: Chronic Oral Reference Dose (RfD).Available online: https://cfpub.epa.gov/ncea/iris/search/ (accessed on 27 February 2021).

25. WHO. Guideline:Potassium intake for adults and children. World Health Organization (WHO): Geneva, Switzerland, 2012; pp. $1-52$.

26. Codex Alimentarius Commission. Joint FAO/WHO food standards programme codex committee on contaminants in foods. Hague, Netherlands, 2011; pp. 1-90.

27. Lewis, J. Codex nutrient reference values.Food and Agriculture Organization of the United Nations and World Health Organization (FAO/WHO). Rome. Italy, 2019; pp. 1-96.

28. Food and Agriculture Organization and Word Health Organization (FAO/WHO), Food Contaminants. In. Codex Alimentarius Commmission. XVII; FAO/WHO, Italy, 1984.

29. Kim, James,H.G., Herman, J., Howe, P.D. World Health Organization. Cobalt and inorganic cobalt compounds. InChemical Safety Team and International Programme on Chemical Safety, 1st ed.; James H. Kim, Herman J. Gibb, Paul D. Howe, Eds.; World Health Organization. Switzerland, 2006; Volume 1, pp. 1 - 93.

30. Lima, N.V.; Arakaki, D.G.; Tschinkel, P.F.S.; Melo, E.S.P.; Caires, A.R.L.; Figueiredo, P.S.; Guimarães, R.C.A.; Hiane, P.A.; Nascimento, V.A. Determination of macro and microelements in whole fruit of Campomanesia adamantium (Cambess.) O. Berg and evaluation of their nutritional potential for children, adolescents and pregnant women. Int. J. Dev. Res. 2017, 7, 13272-13279.

31. Nagajyoti, P.C.; Lee, K.D.; Sreekanth, T.V.M. Heavy metals, occurrence and toxicity for plants: a review. Environ. Chem. Lett. 2010. 8, 199-216, doi:10.1007/s10311-010-0297-8.

32. Bing, H.; Wu, Y.; Sun, Z.; Yao, S. Historical trends of heavy metal contamination and their sources in lacustrine sediment from Xijiu Lake, Taihu Lake Catchment, China. J. Environ. Sci. 2011, 23, 1671-1678, doi:10.1016/S1001-0742(10)60593-1 
33. Institute of Medicine of the National Academes. Part III: Vitamins and Minerals. In Dietary Reference Intake: The essential Guide to Nutrient Requirements, 1st,Otten, J.J., Hellwig, J.P., Meyers, L.D., Eds.; The National Academies Press, USA, 2006, Volume 1, pp. $289-414$.

34. US Department of Agriculture. US Department of Health and Human Services. Food labeling, CFR-Code of federal regulations $\quad 21 . \quad 2019 . \quad$ Available online: https://www.accessdata.fda.gov/scripts/cdrh/cfdocs/cfcfr/CFRSearch.cfm?CFRPart=101\&showFR=1 (accessed on 27 February 2021).

35. He, F.J.; MacGregor, G.A. Beneficial effects of potassium. B.M.J. 2001, 323, 497-501, doi:10.1136/bmj.323.7311.497.

36. Aburto, N.; Hanson, S.; Gutierrez, H.; Hooper, L.; Elliott, P. Effect of increased potassium intake on cardiovascular risk factors and disease: systematic review and meta-analyses. B.M.J. 2013, 346, f1378, doi.https://doi.org/10.1136/bmj.f1378.

37. Weaver, C.M. Potassium and Health. Adv. Nutr. 2013, 4, 368S-377S, doi:10.3945/an.112.003533.

38. Jeong, H.; Jin, H.S.; Kim, S.S.; Shin, D. Identification interactions between dietary sodium, potassium, sodium-potassium ratios, and FGF5 rs 16998073 variants and their associated risk for hypertension in Korean adults. Nutrients 2020, 12, 2121, doi: 10.3390/nu12072121.

39. Elbagermi, M.A.; Edwards, H.G.M.; Alajtal, A.I. Monitoring of heavy metal content in fruits and vegetables collected from production and market places in the Misurata area of Libya. Anal. Chem. 2012, ID 827645, doi:10.5402/2012/827645.

40. Nitu, M.; Pruteanu, A.; Bordean, D.M.; Pospescu, C.; Deak, G.; Boboc, M.; Mustatea, G. Researches on the accumulation and transfer of heavy metals in the soil in tomatoes-Solanum lycopercum. E3S Web of Conferences2019, 112, 03020,https://doi.org/10.1051/e3sconf/201911203020.

41. VasconcelosNeto, M.C.; Silva, T.B.C.; Araújo, V.E.; Souza, S.V.C. Lead contamination in food consumed and produced in Brazil: Systematic review and meta-analysis. Food Res. Inter. 2019, 126, 108671, https://doi.org/10.1016/j.foodres.2019.108671.

42. Cweilag-Drabek, M.; Piekut, A.; Gut, K.; Grabowski, M. Risk of cadmium, lead and zinc exposure from consumption of vegetables produced in areas with mining and smelting past. Sci. Rep. 2020, 10, 3363.

43. Cooke, A. Dietary food-additive phosphate and human health outcomes. Compr. Rev. Food Sci. Food Saf. 2017, 16, 906-1021, doi:10.1111/1541-4337.12275.

44. Trautvetter, U.; Camarinha-Silva, A.; Jahreis, G.; Lorkowski, S.; Glei, M. High phosphorus intake and gut-relate parameters results of a randomized placebo-controlled human intervention study. Nutr. J. 2018, 17, 23,https://doi.org/10.1186/s12937-018-0331-4.

45. Huq, S.M.I.; Joardar, J.C.; Parvin, S.; Correll, R.; Naidu, R. Arsenic contamination in food-chain: transfer of arsenic into food materials through groundwater irrigation. J. Health Popul. Nutr. 2006, 24, 305-316.

46. Oberoi, S.; Barchowsky, A.; Wu, F. The global burden of disease for skin, lung and bladder cancer caused by arsenic in food. Cancer Epidemiol. Biomarkers Prev. 2014, 23, 1187-1194, doi:10.1158/1055-9965.EPI-13-1317.

47. Santra, S.C.; Samal, A.C.; Bhattacharya, P.; Banerjee, S.; Biswas, A.; Majumdar, J. Arsenic in foodchain and community health risk: a study in Gangetic West Bengal. Procedia Environ. Sci. 2013, 18, 2-13, https://doi.org/10.1016/j.proenv.2013.04.002.

48. Shankar, S.; Shanker, U.; Shinkha. Arsenic contamination of groundwater: a review of sources prevalence, health risks, and strategies for mitigation. Sci. World J. 2014, ID 304524,http://dx.doi.org/10.1155/2014/304524.

49. Codex Alimentarius Commission. Food and Agriculture Organization of the United Nations and World Health Organization. Food Additives and Contaminants. Joint FAO/WHO Food Standards Programme, FAO/WHO: Geneva, Switzerland, 2001 ; pp. 1-197.

50. Stranges S., Marshall J.R., Natarajan R., Donahue R.P., Trevisan M., Combs G.F., Cappuccio F.P., Ceriello A., Reid M.E. Effects of Long-Term Selenium Supplementation on the Incidence of Type 2 Diabetes: A Randomized Trial. Ann. Intern. Med. 2007, 147, 217-223, doi:10.7326/0003-4819-147-4-200708210-00175.

51. Behne D., Weiler H., Kyriakopoulos A. Effects of selenium deficiency on testicular morphology and function in rats. J. Reprod. Fertil. 1996, 106, 291-297, doi:10.1530/jrf.0.1060291. 
52. Vézina, D.; Mauffette, F.; Roberts, K.D.; Bleau, G. Selenium - vitamin E supplementation in infertile men. Effects on semen parameters and micronutrient levels and distribution. Biol. Trace Elem. Res. 1996, 53, 65-83, doi:10.1007/BF02784546.

53. Hill, K.E., Zhou J., McMahan W.J., Motley A.K., Burk R.F. Neurological dysfunction occurs in mice with targeted deletion of the selenoprotein P gene. J. Nutr. 2004, 134, 157-161.

54. Miyata, M.; Matsushita, K.; Shindo, R.; Shimokawa, Y.; Sugiura, Y.; Yamashita, M. Selenoneine ameliorates hepatocellular injury and hepatic steatosis in a mouse model of NAFLD. Nutrients 2020, 12, 1898, doi:10.3390/nu12061898.

55. Abbaspour, Z;; Hurrell, R.; Kelishadi, R. Review on iron and its importance for human health. J. Res. Med. Sci. 2014, 19, 164-174.

56. Pasricha, S.R.; Low, M.; Thompson, J.; Farrell, A.; De-Regil, L.M. Iron supplementation benefits physical performance in women of reproductive age: A systematic review and meta-analysis. J. Nutr. 2014, 144, 906-914.

57. Georgieff, M.K.; Krebs, N.F.; Cusick, S.E. The benefits and risks of iron supplementation in pregnancy and childhood. Annu. Rev. Nutr. 2019, 39, 121-46, https://doi.org/10.1146/annurev-nutr-082018-124213.

58. WHO. Molybdenum in drinking-water. Background document for development of WHO Guidelines for drinking-water quality. World Health Organization. Geneva, Switzerland, 2003; pp. 1-12.

59. Moss, M. Effects of molybdenum on pain and general health: A pilot study. J. Nutr. Environ. Med. 1995, 5, 55-61, https://doi.org/10.3109/13590849509008762.

60. Schwarz, G.; Mendel, R.R.; Ribbe, M.W. Molybdenum cofactors, enzymes and pathways. Nature 2009, 460, 839-847, doi:10.1038/nature08302.

61. Novotny, J.A. Molybdenumnutriture in humans. J.E.B.C.A.M. 2011, 16, 164-168,doi:10.1177/22156587211406732.

62. Tsongas, T.A.; Meglen, R.R.; Walravens, P.A.; Chappell, W.R. Molybdenum in the diet: an estimate of average daily intake in the United States. Am. J. Clin. Nutr. 1980, 33, 1103-1107.

63. Chasapis, C.T.; Loutsidou, A.C.; Spiliopoulou, C.A.; Stefanidou, M.E. Zinc and human health: an update. Arch. Toxicol. 2012, 86, 521-534, doi:10.1007/s00204-011-0775-1.

64. Roohani, N.; Hurrell, R.; Kelishadi, R.; Schulin, R. Zinc and its importance for human health: An integrative review. J. Res. Med. Sci. 2013, 18, 144-157.

65. Ugarte, M.; Osborne, N.N.; Brown, L.A.; Bishop, P.N. Iron, zinc, and copper in retinal physiology and disease. Surv. Ophthal.2013, 58, 585-609, http://dx.doi.org/10.1016/j.survophthal.2012.12.002.

66. Czarnek, K.; Terpolowska, S.; Siwicki, A. Selected aspects of the action of cobalt ions in the human body. Cent. Eur. J. Immunol. 2015, 40, 236-242, doi:10.5114/ceji.2015.52837.

67. Leyssens, L.; Vinck, B.; Straeten, C.; Wuyts, F.; Maes, L. Cobalt toxicity in humans-A review of the potential sources and systemic health effects. Toxicology 2017, 387, 43-56, doi:10.1016/j.tox.2017.05.015.

68. Onianwa, P.C.; Lawal, J.A.; Ogunkeye, A.A.; Orejimi, B.M. Cadmium and Nickel composition of Nigerian foods. J. Food Compos. Anal. 2000, 13, 961-969, doi:10.1006/jfca.2000.0944.

69. Zambelli, B.; Ciurli, S. Nickel and human health. Met. Ions Life Sci. 2013, 13, 321-357, doi:10.1007/978-94-007-7500-8_10.

70. Genchi, G.; Carocci, A.; Lauria, G.; Sinicropi, M.S.; Catalano, A. Nickel: Human health and enronmental toxicology. Int. J. Environ. Res. Public Health 2020, 17, 679, doi 10.3390/ijerph17030679.

71. Marles, R.J. Mineral nutrient composition of vegetables fruits and grains: the context of reports of apparent historical declines. J. Food Compos. Anal. 2017, 56, 93-103.

72. Lee, J.J.; Valeri, L.; Kapur, K.; Hasan, M.O.I.; Quamruzzaman, Q.; Wright, R.O.; Bellinger, D.C.; et al. Growth parameters at birth mediate the relationship between prenatal manganese exposure and cognitive test scores among a cohort of 2- to 3year-old Bangladeshi children. Int. J. Epidemiol. 2018, 47, 1169-1179, doi:10.1093/ije/dyy069.

73. Kupsco, A.; Sanchez-Guerra, M.; Amarasiriwardena, C.; Brennan, K.J.M.; Estrada-Guitierrez, G.; Svensson, K.; et al. Prenatal manganese and cord blood mitochondrial DNA copy number: Effect modification by maternal anemic status. Environ. Int. 2019, 126, 484-493, doi:10.1016/j.envint.2019.02.029. 
74. Lopez, C.A.; Skaar, E.P. The impact of dietary transition metals on host-bacterial interactions. Cell Host Microbe. 2018, 23, 457 737-748, doi:10.1016/j.chom.2018.05.008.

75. Cherfi, A.;Abdoun, S.; Gaci, O. Food survey: levels and potential health risks of chromium, lead, zinc and copper content in 459 fruits and vegetables consumed in Algeria. Food Chem. Toxic. 2014, 70, 48-53. http://dx.doi.org/10.1016/j.fct.2014.04.044.

76. World

Health Organization.

Health diet.

Available 461 online:https://www.who.int/news-room/fact-sheets/detail/healthy-diet\#: :text=Eating\%20at\%20least\%20400\%20g,daily\%20int ake\%20of\%20dietary\%20fibre (accessed 27 February 2021). 